\title{
THE LANDFILL BIOCELL AS AN ECOFILTER FOR RECYCLING OF BIO-ENERGY AND NUTRIENTS FROM RESIDUAL WASTES
}

\author{
Torleif Bramryd \\ Michael Binder \\ University of Lund, SWEDEN
}

\begin{abstract}
Anaerobic fermentation in landfill reactorcells is a biological waste treatment technique where both energy and nutrients can be recovered. The landfill reactorcell ("biocell") serves as an ecological filter, where energy is extracted as biogas while nutrients are recovered through the leachates and can be used as fertilizer in e.g. energy forests, and thus brought back to an ecological cycling. At the same time anaerobic conditions result in an effective immobilization of heavy metals and other pollutants e.g. as insoluble metal sulphides, which are immobilized in the fermentation rest.
\end{abstract}

The long-lived fraction, remaining after the fermentation process has declined, containing a high content of lignin, serves as a water-holding matrix, which helps to enforce a sustainable high moisture level, and thus sustainable anaerobic conditions with heavy metals retained on a longterm bases. Also non-degradable products, like plastics, help to shield off oxygen and maintain reliable anaerobic conditions.

Landfilling of organic matter is a measure to counteract the increasing concentrations of $\mathrm{CO}_{2}$ in the atmosphere, resulting from different human activities. Landfilling at anaerobic conditions means that a small fraction of the organic matter is long-term accumulated in the landfill. Accordingly landfills have similar carbon accumulating effects as natural peatlands and lake or sea sediments.

With low investment costs it is possible to convert traditional landfills to well controlled biological treatment facilities. Thus the technique can be performed both in large and small scale, avoiding energy demanding road transportation.

\section{Introduction}

Biological waste treatment can include aerobic composting of mixed or source separated wastes, anaerobic reactor fermentation or fermentation in bioreactors (reactorcells) constructed in landfills. Each technique is appropriate for a certain spectrum of wastes 
(Bramryd 1997a,b, 1999). It is of great importance to identify the best available options for different types of wastes. The aim of a biological/ecological waste treatment is to resemble natural ecological processes as much as possible and to achieve as closed systems as possible.

Treatment of leachates in biofilters, like energy forests or grass-plantations within the landfill area, is an environmentally advantageous technique to retain nutrients and pollutants within a controlled area. At the same time nutrients in the leachates can be used to promote a high biomass production. Produced biomass can be fermented or incinerated for energy recovery. Earlier research investigations indicate that the concentrations of e $g$ heavy metals normally are low in such irrigated biomass (Bramryd 1983). Thus the flux of heavy metals from the landfill per time unit is probably small.

Extraction of methane gas for energy production in combination with the utilization of leachates as fertilizer means that the landfill will be a sealed system with strongly reduced risks for contamination of the environment (Bramryd 1997b). With a combined system for optimized methane gas production and leachate utilization for energy biomass production, the total energy yield per ton original waste could in the future be comparable to that of direct incineration. At the same time investment costs and environmental effects are considerably lower with the biological technique.

\section{Design of landfill reactorcells}

Reactorcells for optimized fermentation of residual solid wastes are constructed within the ordinary landfill area. Each reactorcell consists of a well defined unit, normally with separate gas and leachate collection systems. The bottom of the cells should be covered by a layer with low permeability (clay, bentonite or plastic liners). The reactorcells are surrounded by earth walls, which during the filling period serve as a shield against insight and as a protection against windblown paper and plastics (Meijer and Bramryd 1994).

The amount of waste landfilled per day determines the size of the reactorcells. As a rule one reactorcell should be filled within 2 years. In order to avoid diffuse transportation of methane to the atmosphere, the open, active surface should be as small as possible, and the collection of methane should start already during the filling period. In a large and developed biogas system the relatively low methane content of the gas collected from the fresh waste is normally compensated by the high methane content from older parts of the reactorcell landfill.

In order to facilitate the transportation of methane gas and leachates in the reactorcell, clay and sand should be avoided. Thus woodchips or waste wood homogenized by the compactor wheels can be used for the construction of roads within the bioreactor, as a substitute for sand and gravel (Bramryd 1997a). Waste wood, bark, the coarse fraction from sieving of compost or any related material can be used for the daily cover of the waste. This cover material will take part in the biological reactions and will during decomposition contribute to the produced methane gas or to the nutrients collected through the leachates. Therefore it is an environmentally friendly way to use painted or impregnated wood (demolition wood), furniture, etc, which due to a high contamination of heavy metals should not be directly burned in a power plant. In this way the energy will be recovered through the methane gas, while the heavy metals will be firmly fixed to the fermentation rest, left in the landfill. 
In order to minimize penetration of air into the bioreactor, due to an established underpressure linked to the methane extraction from the cells, a top cover of clay or related material should be used.

This cover will also decrease the amounts of leachates. The top cover, bottom-liner and drainage layers function as an isolation from the environment (Murphy et al. 1995). As a covering material as well as structure material for the walls, a layer of waste plastics (polyethylene) might have a similar function than clay. If a thick vegetation cover can be established on the top surface, this will decrease the amounts of leachates even more.

\section{Enhanced biogas production}

The yield of biogas from the anaerobic degradation in the reactorcell depends largely on the type of waste in the reactorcell. A mixture of municipal, commercial and light industrial waste has been shown to give the best yield of methane gas. The amounts of gas generated thus depend on the chemical composition of the waste, that is the relations between organic carbon and nitrogen ( $\mathrm{C} / \mathrm{N}$ ratio), carbon and phosphorus (C/P ratio) and the ratios between nitrogen and magnesium, potassium and calcium. Also the moisture content and the physical structure are of great importance. Thus it is of importance to have a mixture of food waste and material rich in cellulose (paper, wood, etc). Plastics on the other hand can help to decrease the amounts of air penetrating down in the waste to facilitate stabilized anaerobic conditions. Polystyrene cups and related hard plastics can act as stabilizers in the landfill bioreactor facilitating the transportation of methane to the extraction points. Coarser material like crushed furniture and other waste wood can act as such a stabilizing material, too. If the waste has a low moisture content, and if there is a lack of structural material, there is a risk for building up zones with a poor water drainage capacity. Water can accumulate and the production of organic acids can lead to decreasing $\mathrm{pH}$ levels resulting in decreased methane production. Such wet zones also prevent the gas transportation.

A relation between carbon and nitrogen (the $\mathrm{C} / \mathrm{N}$ ratio) of about $50-70$ is regarded as optimal for landfill reactorcell fermentation. This is a higher ratio than is normally optimal in steel reactor fermentation. Food waste normally has a $C / N$ ratio of about 20 . This means that the cellulose content in the solid waste (paper- and woodproducts) is of great importance as a carbon source during the methane production. Thus separation of municipal waste in a wet and a dry fraction, where the wet fraction is intended for reactorcell treatment, will give a much lower yield of methane than if the mixed waste was fermented in the reactorcells. A low $\mathrm{C} / \mathrm{N}$ ratio will probably cause an accumulation of fatty acids, intermediate substances formed during the methane formation process (Welander et al 1992). In steel reactor fermentation on the other hand separated food should be used to achieve a $\mathrm{C} / \mathrm{N}$ ratio of about 20-30. Relatively low demands of nutrients for the landfill reactorcell fermentation process further mean that reactor fermentation or composting of a source separated food fraction from the waste does not negatively affect the possibilities for landfill reactorcell fermentation. The landfill cell fermentation is sooner an alternative to mass-incineration than to composting or other biological treatment techniques.

The total annual amount of methane extracted from the reactorcells is estimated to approximately $200-250 \mathrm{~m}^{3}$ methane per ton landfilled waste, or about $15-25 \mathrm{~m}^{3}$ of methane per ton waste and year. The biogas presents a methane concentration of about $40 \%$ already a few months after landfilling, and reaches after about 1-2 years a stable value of about $60-65 \%$ methane (Bramryd 1997a). 


\section{Reactorcells as ecological filters}

Leachates are produced in the landfill reactorcell at different rates, depending on mainly the rainfall which shows a linear relationship to leachate generation (Chen 1996). The chemical composition of leachates gives an important indication of the composition of the waste as well as of the microbiological degradation processes. At the same time the quality of the leachates is of importance from an environmental point of view. Stabilized anaerobic conditions in combination with the supply of organic material normally means a low concentration of heavy metals in the leachates (Bramryd 1988a, Bramryd and Fransman 1985). During anaerobic conditions heavy metals form insoluble metal-sulphides, which catch heavy metals released during mineralization processes (Bramryd 1991, Reinhart et al. 1996). In addition to this, solid organic material has a good ability to bind up heavy metals with organo-metallic colloid-bindings (Tyler 1978; Kerndorff and Schnitzer 1980; Bramryd 1988 b). Thus stabilized anaerobic conditions at an early stage will guarantee a high level of methane gas recovery at the same time as the leaching of heavy metals will decrease.

Nutrients like magnesium, potassium, sodium, and calcium do not form insoluble metal sulphides under anaerobic conditions and therefore appear, in contrast to heavy metals, in the leachate.

Thus the reactorcell acts as an anaerobic filter, enabling a separation of the nutrients from a mixed waste. The toxic heavy metals are bound up in the fermentation rest, whereas the nutrients are recovered. If the leachates are used as fertilizer in e. g. energy plantations, forestry, etc, the nutrients can be brought back to an ecological cycling. This possibility will not be offered after incineration where the ashes, due to the high amounts of easily available heavy metals, are recommended to be landfilled in sealed monofills.

Most of the methane gas will be extracted during a 10-15 year period. However also after this period anaerobic conditions will probably dominate over an extensive time scale. Many landfills are placed in depressions or wetlands, and it is relevant to believe that much of the minerals left after a future reduction of the organic contents, still will be bound up under anaerobic conditions. This is of ultimate importance for the extraction of nutrients, as mentioned above. This also means that the reactorcells should not be excavated, as this would lead to oxidation of the metal sulphides, and thus to a mobilization of heavy metals to the leachates. The fermentation rest should instead be left in the landfill.

Due to settings in the landfill during the mineralization of the waste, up to $50 \%$, additional space is achieved. New reactorcells can thus be constructed on top of the old ones, and the fermentation rest containing a concentrate of heavy metals, organic carbon from fossil material like plastics, etc, will efficiently be long-term accumulated. This is important from a biogeochemical point of view.

There are several options for recirculation of nutrients from leachates to vegetation systems. The most common practice is to use the leachates in plantations with different Salix-species and on grasslands, but also other plant communities are possible for leachate recycling. For example at the NSR landfill in Helsingborg, South Sweden, the leachates from the reactorcells are transported to a young birch forest (Betula pubescens) where the leachates are spread on the soil surface with trenches flooded at intervals. Birch has a very good capacity to evaporate water and the potential for increased biomass production during increased amounts 
of available nutrients is extremely good. In addition to this birch forest also plantations with willow (Salix viminalis) will be irrigated with leachates.

\section{Landfill reactorcells as moderators for the global $\mathrm{CO}_{2}$ balance}

Landfills can be regarded as the anthropogenic counterpart to natural peatlands and lake sediments, i. e. ecosystems with a capacity to accumulate organic carbon, which thus can balance the increased atmospheric concentrations of $\mathrm{CO}_{2}$. The annual accumulation of organic carbon in the World's landfills has been estimated to around $100 \times 106$ metric tons of C (Bramryd 1982, 1983). The size of the long-term accumulated fraction depends on the conditions for decomposition in the landfill.

During landfilling most of the organic carbon in fossil derived products, like plastics and other synthetic materials, will be brought back to long-term accumulation. As these products only to a very small extent take part in the methane gas production, the landfill gas (biogas) can be regarded as a true biofuel. In contrast to incineration, a high moisture content in the waste will not decrease the yield of energy per ton of waste.

The long-lived organic material left in the fermentation rest in the landfill can, to a large extent, be derived to lignin compounds in the waste. Lignin compounds also make up for a major part of the litter fractions creating humus under aerobic conditions. Thus the organic matter contributing to the methane formation in a landfill reactorcell is normally short-lived, also in a natural aerobic environment, and thus has a short turn-over time. The reactorcell fermentation technique thus conforms very well with the natural $\mathrm{CO}_{2}$ cycle.

A landfill reactor-cell, treating approximately 100000 tons of waste per year, and where the fermentation residues are left in the landfill, a fraction of about $7: 13000$ tons of organic carbon is long-term accumulated each year (Bramryd 1997c). This equals the total amount of carbon in approximately 65 hectares of grown-up spruce forest, or approximately 45 hectares of deciduous forest (Whittaker and Likens 1975; Bramryd 1997c). With another comparison it can be concluded that the deposition of organic matter in a well controlled landfill compensates for a large proportion of the $\mathrm{CO}_{2}$ emissions from cars, busses and lorries in the surroundings. The long-lived fraction, that after some decades remains from the entire volume annually being landfilled in reactorcells and landfills in Sweden, equals the organic carbon in approximately 3 $000 \mathrm{~km}^{2}$ of grown-up spruceforests. Thus if all the waste, that today is treated in landfills or landfill reactor-cells, instead would have been quickly oxidized in incinerators, the effects on the global $\mathrm{CO}_{2}$ balance would have been equal to a situation where $3000 \mathrm{~km}^{2}$ of mature spruce forests were clear-cut each year, without replanting.

During landfilling of plastics or synthetic rubber, i.e. products containing organic carbon with fossil origin, organic carbon is rerouted to a long-term accumulation in the ground, and will thus not contribute to a net-increase of the atmospheric $\mathrm{CO}_{2}$ - concentrations. It is of great importance to establish carbon accumulating functions in the urban society, as the natural $\mathrm{CO}_{2}$ balancing processes are insufficient to compensate for the increasing emissions of carbon dioxide. 
Methane has a high energy content and is a good and clean fuel. On the other hand if methane is allowed to escape to the atmosphere it can act as a severe greenhouse gas since it has an approximately 20 times higher (Krumbolz et al 1995, Christensen 1991, ICCP 1995) radiative forcing than $\mathrm{CO}_{2}$. However modern research has shown, that the emissions from landfills are at much lower rates than earlier expected, mainly due to methane oxidizing bacteria. Thus even if there are no biogas collection systems, the amounts of produced methane is reduced by approximately a factor 10 before it can escape to the atmosphere.

With an annual accumulation of organic carbon in spruce forests of about $2.5 \times 10^{6} \mathrm{~g} \mathrm{C}$ per hectare the annual accumulation of long-lived carbon in the Filborna landfill in Helsingborg, South Sweden, corresponds to the annual increment of carbon in 6800 hectare of temperate spruce forests. In addition to the accumulation of organic carbon resistant to mineralization, landfilling also means an increasing amount of organic matter, which, in spite of microbial degradation, will be accumulated during a few years. Thus the positive effects on the carbon balance are not only related to the most long-lived fractions which finally will be stored for a very long period of time.

The total annual amount of mixed municipal and industrial waste that is landfilled in Sweden at present can be estimated to around $3 \times 10^{6}$ ton (SOU 1996), corresponding to approximately $0.75 \times 10^{12} \mathrm{~g} \mathrm{C}$. Of this fraction about $0.40 \times 10^{12} \mathrm{~g} \mathrm{C}$ organic carbon can be regarded as resistant to degradation under normal landfill conditions. The accumulation of long-lived carbon in landfills in Sweden is about $25 \%$ of the total accumulation in peat per year or about $5 \%$ of the total accumulation of organic carbon in annually produced biomass in Sweden. The total annual accumulation of organic carbon in landfills in Sweden corresponds to the annual increase of carbon in $3000 \mathrm{~km}^{2}$ of spruce forest. At the same time about $2 \times 10^{6}$ tons of waste is incinerated each year in Sweden, resulting in a release of about $0.50 \times 10^{12} \mathrm{~g} \mathrm{C}$. A fraction of about $0.30 \times 10^{12} \mathrm{~g} \mathrm{C}$ would have been more or less long-term accumulated if this amount of waste instead would have been landfilled. Table 1 shows major annual accumulations and releases of carbon in Sweden. (Bramryd 1997c)

In Sweden the alternative to waste incineration for energy production would in most cases have been combustion of woodchips or other renewable fuels, which, if not bumed, anyhow would have had a short turn-over time. Thus burning of woodchips only have a small net effect on the global $\mathrm{CO}_{2}$ balance.

In waste dominated by wood and paper products the lignin concentrations can be estimated to about 10-20\%. In spite of a higher carbon oxidation rate during optimized reactorcell fermentation this new technique is beneficial from a total $\mathrm{CO}_{2}$ point of view. Biogas has a high fuel efficiency during combustion and compared to many other fuels the production of $\mathrm{CO}_{2}$ is low calculated per produced energy unit.

During incineration of solid waste most of the organic carbon will be emitted as $\mathrm{CO}_{2}$, including carbon derived from fossil material. Due to a high moisture content in municipal solid waste energy will be consumed and $\mathrm{CO}_{2}$ produced for the evaporation of water. This contributes to the negative effects of waste incineration on the atmospheric carbon balance.

If energy production through waste incineration was replaced by biological energy extraction from waste and if biofuels like straw, woodchips from forest residues or energy forests were 
used instead the effects on the global carbon dioxide balance could be decreased. Planting of an energy forest within a landfill area will also immobilized $\mathrm{CO}_{2}$ in. standing biomass. In such a forest plantation supplied by nutrients extracted from the waste in connection to an utilization of leachates for irrigation, organic carbon corresponding to approximately 10 ton of organic carbon can be stored per hectare each time unit, in spite of a short turn-over time for the produced biomass.

\section{References}

Bramryd T 1982. Fluxes and accumulation of organic carbon in urban ecosystems on a global scale. - In Urban Ecology (Bornkamm, Lee and Seaward eds.), Blackwell Scientific Publications, Oxford, 3-12.

Bramryd T 1983. Human Impact on the Biogeochemical Cycling of Carbon Between Terrestrial Ecosystems and the Atmosphere. - In Environmental Biogeochemistry (Hallberg ed), Ecol.Bull (Stockholm) 35, 301-313.

Bramryd T and Fransman B 1985. Utvärdering av äldre gödslings- och kalkningsförsök med torv- och vedaska i Finland och Sverige. - Statens Naturvårdsverk PM 1991.

Bramryd T 1988a. Leaching of heavy metals from solid waste incinerator ashes. - In Brown, Evemy and Ferrero (eds.). Energy recovery through waste combustion, 326-329. CEC. Elsevier, London and New York.

Bramryd T 1988b. Leachate from landfills - a valuable fertilizer for revegetation of landfills with grass or energy forests. In Andersen and Møller (eds) ISWA 88. Proceedings of the 5th Int Solid Waste Conference. Vol 2:61-68. Academic Press, London.

Bramryd T 1991. Research on optimized landfill gas production in Sweden. - In: Landfill Gas, Energy and Environment '90, (Richards G E and Alston Y R (eds)), United Kingdom Deparment of Energy and Department of the Environment. Harwell Laboratories, Oxfordshire, 607-614.

Bramryd T 1997a. Landfilling in the perspective of the global CO2 balance, In: Environmental impact, aftercare and remediation of landfills. In: (T.H.Christiansen, R.Cossu, R.Stegman, eds), Vol IV, 11-16. CISA, Environmental Sanitary Engineering Centre, Cagliari.

Bramryd T 1997b. Biological waste treatment techniques from an ecological viewpoint. ISWA Yearbook 1997/98, 68-75.

Bramryd $T$ 1997c. Landfilling in the perspective of the global CO2 balance, In: Environmental impact, aftercare and remediation of landfills. In: (T.H.Christiansen, R.Cossu, R.Stegman, eds), Vol IV, 11-16. CISA, Environmental Sanitary Engineering Centre, Cagliari. Bramryd T 1999. Process performances for biological treatment of solid wastes. - Proc. Specialized Conf "Biological Processing of waste: A solution for tomorrow", Paris, 11-12 March 1999. Association Générale des Hygiénistes et Techniciens Municipaux, Paris, France, 13 pp. 
Chen P H 1996. Assessment of leachates from sanitary landfills: impact of age, rainfall, and treatment. Environmental International 22(2), 225-237

DOI: https://doi.org/10.1016/0160-4120(96)00008-6

Christensen T R 1991. Arctic and sub-Arctic soil emissions: possible implications for global climate change, Polar Record 27 (162), 205-210

DOI: https://doi.org/10.1017/S0032247400012584

ICCP 1995. Non Tidal Wetlands, Chapter 6, p.217-234, Cambridge University Press

Krumholz C R, Hollenback J L, Roskes S J, and Ringelberg D B 1995. Methanogenesis and methanotrophy within a Sphagnum peatland, FEMS Microbilogy-Ecology, Vol. 18, p.215-224, DOI: https://doi.org/10.1016/0168-6496(95)00061-4

Meijer J E and Bramryd T 1994. Landfill cells for biogas generation. Case study. ISWA Yearbook 1994/95.

Murphy R J, Jones D E, and Stessel R I 1995. Relationship of microbial mass and activity in biodegradation of solid waste, Waste Management and Research 13, 485-497

DOI: https://doi.org/10.1016/S0734-242X(05)80026-6

Reinhart D R, and Al-Yousfil A B 1996. The impact of leachate recirculation on municipal solid Waste landfill operating characteristics, Waste Management and Research 14, 337-346 DOI: https://doi.org/10.1006/wmre.1996.0035

SOU (1996) Skatt på avfall. Slutbetänkande av Deponiskatteutredningen. Statens Offentliga utredningar, 1996:139. Finansdepartementet, Stockholm, 459 pp.

Tyler G 1978. Leaching rates of heavy metal ions in forest soil. Water, Air and Soil Pollution 9, 137-148.

Welander, T., Bramryd T., Meijer J.-E., and Persson B.-L. 1992. The effect of different control actions on the anaerobic microbial production of biogas in landfills. In: Proc. 6th Int. Solid Wastes Congress and Exhibition, Madrid, June 1992, ISWA, 10 pp.

Whittaker R.tH. \& Likens G. E. (1975) The bioshere and man. In: Lieth H. and Whittaker R.tH. (eds). Primary Productivity of the Biosphere. Ecol. Stud. 14, 305-328, Springer-Verlag, Berlin, Heidelberg, New York.

The Northwest Scania Solid Waste and Recycling Company (NSR), handling approximetely 500000 tons of solid waste per year is today one of the pioneer companies in Scandinavia with this new technique. This paper describes scientific investigations on optimized methane gas production and waste stabilization performed at the NSR plant in Helsingborg, South Sweden.

\section{The Filborna Bioreactor program}

\section{Aim of the program}

At Northwest Scania Recycling Company test-cell experiments as well as full scale operation of reactorcells (biocells) are peiformed. 
The test cell project started in 1989, partly funded by the Swedish National Board for Industrial and Technical Development, focuses on the effects of moisture, temperature and $\mathrm{pH}$ buffering on the methane gas production and the leachate quality. The aim of the test-cell program is also to find detailed routines for an optimized biological treatment of municipal solid wastes for energy extraction. The research project focuses on the effects of waste composition and especially the nutrient balance in the waste. Methane production and leachate quality are essential parameters used for the final evaluation of the fermentation process. The nutrient concentrations of the leachates are especially focused on as a potential fertilizer in e.g. energy forest plantations.

\section{2 Experimental design}

Four testcells, each with the dimensions of $40 \times 40 \times 10 \mathrm{~m}$ and containing approximately 15 $000 \mathrm{~m}^{3}$, were each filled with approximately 13500 tons of domestic, commercial and light industrial wastes. Each waste layer was approximately $2 \mathrm{~m}$ thick, and covered with woodchips. During periods with heavy rainfalls woodchips was also used to stabilize the tipping area to faciliate the delivery of waste by trucks.

The testcells were constructed on a former landfill with approximately $3-4 \mathrm{~m}$ of waste underneath, but were insolated in the bottom by approximately $1 \mathrm{~m}$ of clay.

In the bottom of the cells two systems of perforated plastic tubes were placed in a horizontal, symmetric pattern for the collection of landfill gas and leachates. The tubes are covered by a layer of gravel. A similar system for landfill gas collection was also placed at $5 \mathrm{~m}$ above the bottom surface.

Each cell is equipped with two lysimeters with a surface of $2.5 \times 5 \mathrm{~m}^{2}\left(12.5 \mathrm{~m}^{2}\right)$. The volume of collected leachates and the chemical quality is measured regularly.

Cell 1 Domestic and light industrial waste. Reference cell

$\begin{array}{ll}\text { Cell } 2+ & + \text { irrigation with fresh water } \\ \text { Cell } 3 & + \\ \text { Cellt4 - } & \text { addition of air to increase the microbial } \\ \text { activity and the temperature }\end{array}$

The filling of waste started during the summer 1990 and continued for approximately one year. After filling the first $2 \mathrm{~m}$ of the bottom of the cells, infilling of waste seased for a period of about 2 months in order to achieve a pre-composting of the bottom waste.

In addition to the testcells there are at present four full scale reactorcells at the Filborna landfill. Each cell was filled within approximately one year. The gas extraction system was installed already during the waste filling period, and the extraction also started during this period. This ensures that no methane escapes to the atmosphere during the first period. Each of the full scale reactorcells has a surface of approximately 100-200 m x 80-90 m and a hight of approximately $10 \mathrm{~m}$. 
The waste has been brought into the cells with ordinary landfill equipment. A 33 ton compactor (Caterpillar $826 \mathrm{C}$ ) treat and compact the waste by 5-6 overpasses. The waste delivering cars unload the waste at a separate tipping-surface and the waste is pushed over the surface of the reactorcell with the compactor.

The leachates from the full scale reactorcells are collected through two plastic drains at the bottom of each cell. The gas is collected through horizontal plastic drains placed in every second lift, 30-50 m apart. The horizontal drains are used to extract the landfill gas during the filling of the cells. Avter the reactorcells are completed the extraction system is improved by additional vertical gas wells.

\section{3 Waste composition}

The waste in the test cells, as well as in the full scale cells, is a mixture of domestic, commercial and light industrial wastes from the cities of Helsingborg, Ängelholm and Höganäs and the communities of Bjuv, Båstad and Åstorp. The light industrial waste include food industry waste, waste from fruit and vegetable importers, wastes from trains and ferries, a s 0 . The reactorcells also contain a high proportion of waste rich in paper and other cellulose compounds. The waste can be regarded as typical for a heavily populated area in Scandinavia with a well developed system for material recovery (paper, plastics, glass, metals, gardenwaste for composting, etc), and with no waste incineration.

The waste also contains a rather high proportion of polyethylene plastics, which helps to shield off the reactorcells from penetrating air.

Detailed, computerized information about the weight of the different types of wastes was obtained from the entrance control. 


\section{4 Sampling and analyzation}

Leachates collected from the lysimetres were concentrated and chemically digested in concentrated nitric acid before analyzation with an ICP technique (Inductively coupled plasma technique). The concentrations of $\mathrm{P}, \mathrm{Na}, \mathrm{K}, \mathrm{Ca}, \mathrm{Mg}, \mathrm{B}, \mathrm{S}, \mathrm{Al}, \mathrm{Fe}, \mathrm{Ba}, \mathrm{As}, \mathrm{Cd}$, $\mathrm{Co}, \mathrm{Cr}, \mathrm{Cu}, \mathrm{Mn}, \mathrm{Mo}, \mathrm{Ni}, \mathrm{Pb}$ and $\mathrm{Zn}$ were analysed 